\title{
Introduction to the special issue "Young People and New Geographies of Learning and Education"
}

\author{
Itta Bauer and Sara Landolt \\ Department of Geography, University of Zurich, Winterthurer Strasse 190, 8057 Zürich, Switzerland \\ Correspondence: Itta Bauer (itta.bauer@geo.uzh.ch) and Sara Landolt (sara.landolt@geo.uzh.ch)
}

Received: 6 November 2017 - Revised: 12 December 2017 - Accepted: 19 December 2017 - Published: 14 February 2018

\section{Background and contextualization}

Over the last 20 years, children's and young people's geographies have become established as a vibrant field of research within Anglo-American geography. However, the enthusiasm within the discipline for issues relating to young people has arisen mostly in English-speaking countries and has generated only a moderate echo in German-speaking countries. As the two authors of this paper have been engaged in research on the geographies of young people in Germany and Switzerland, both felt the need to fill the gap and address this special issue. We collected the names of research teams and individual researchers within and beyond geography who were studying children and young people in Germany and Switzerland and invited them to join a workshop titled "New approaches to Children, Young People and Education" at the University of Zurich in 2014. An international and multidisciplinary group of about 25 researchers accepted our invitation and openly exchanged their expertise on ongoing research projects and findings. Following this positive experience, we decided to extend this emerging network by sharing the exciting theoretical debates and the empirical findings presented at the workshop with the wider readership of Geographica Helvetica.

Human geographers from diverse academic backgrounds have appreciated the experiences of children and young people as worthwhile sources for new theoretical and empirical discussion (e.g. Aitken, 2001; Ansell, 1999; Cahill, 2000; Holloway and Valentine, 2000; Holloway et al., 2010; Johnston et al., 2000; Katz, 2004; McDowell, 2002; Nayak, 2003; Skelton and Valentine, 1998). Many of these have tended to engage in more detail with young people's everyday spaces of learning, both in formal education and in informal settings (Gagen, 2000; Mills and Kraftl, 2014; Robinson, 2017).
In a virtual special issue on the geographies of education and learning of the Transactions of the Institute of British Geographers, Holloway and Jöns provide a definition of this wide field of interest:

Geographies of education and learning consider the importance of spatiality in the production, consumption and implications of formal education systems from pre-school to tertiary education and of informal learning environments in homes, neighbourhoods, community organizations and workspaces. (Holloway and Jöns, 2012:482)

This definition not only summarizes the great variety of perspectives but also indicates the different traditions within geographies of education, especially in Great Britain, and Bildungsgeographie in Germany (Freytag and Jahnke, 2015; Meusburger, 1998). Our own engagement with this body of research is at least partly motivated by a growing unease with the continuous reliance on essentialist categorizations and binary structures, such as adolescents-adults, subjects-objects, global-local, or informal-formal learning in a diverse literature. Similar observations have already been made in the contexts of young people, transitions, and boundary crossings (e.g. Hörschelmann, 2011; Fenwick, 2013; Valentine, 2003) and children's geographies of global-local interconnections (Ansell, 2010; Katz, 2017). The intent of this special issue is to connect with and continue this ongoing discussion.

The contributions to this special issue critically engage with established binaries and structures not only in formal education (e.g. primary, secondary and tertiary education) but also more generally in more informal or alternative settings of learning. This approach does not seek to explain away contradictions, paradoxes, or uncertainties but instead to acknowledge and confront these questions and issues. Consequently, the special issue attempts to contribute to a 
more complex understanding of the messiness of things - including research (Law, 2004). In this ever-changing context, questions of where, when, and how learning and education happen require innovative approaches that have the potential to dissolve established binaries and to grasp heterogeneous ideas, objects, subjects, and bodies as constituent parts of fluid "learning networks" (Leander et al., 2010:344ff.). This line of thought requires us to understand learning as an integrative concept involving people of different ages, abilities, geographies, his and herstories, futures, and anything else that is non-human.

We believe that the inspiring empirical examples and arguments gathered in this special issue will enrich current debates about young people within geographies of learning and education.

\section{Three themes for the special issue}

We would like to set a theoretical frame for the collected papers focusing on three themes in particular:

1. movement and transition

2. spaces and identities

3. education and assemblages.

\subsection{Movement and transition}

We build on transition, a core concept within youth studies and young people's geographies that has undergone various theoretical and methodological changes. This concept often relates to the transition from one educational context to another, such as the transition from elementary to secondary school or from compulsory education to postcompulsory education or work (Holloway and Jöns, 2012; Bitzi and Landolt, 2017, in this special issue; Rérat, 2016, in this special issue). These educational transitions certainly involve processes of selection that reproduce social inequalities and thus are both important and relevant for engaged research and practice (Bauer, 2018, in this special issue). An overly static and linear pattern of thinking about youth transitions has been criticized over the last two decades by many scholars for failing to account both for biographical ruptures and discontinuities and for the delayed, multiple, and uncertain transitions that are part of young people's everyday lives (Hörschelmann, 2011:379; also Cuervo and Wyn, 2014; Brown et al., 2012; Evans, 2008; MacDonald et al., 2005; Valentine, 2003; Skelton, 2002; Hörschelmann, 2018, in this special issue). By juxtaposing movement with transition, we focus on these critiques. Transitions themselves are fluid and in movement. For instance, scholars researching migration, transitions, and education have advocated broader thinking about youth transitions. They argue that immigrant youth are likely to be affected by translocal lives and experience complex intersections of educational transitions and migration (e.g. Robertson et al., 2018; Smith et al., 2014; Tse and Waters, 2013; Brooks et al., 2012; Bitzi and Landolt, 2017, in this special issue). Patrick Rérat's article draws on rich empirical material from Switzerland and addresses internal migration that occurs during the transition from higher education to the labour market. He conceptualizes migration choices as the outcome of combining a variety of rationales, including affective (social and love life), sensitive (residential amenities), and utilitarian (job opportunities) as much as calculating logics (financial elements). The article thus demonstrates that migration decisions in the context of transition from higher education to the labour market depend on a variety of constraints.

Transitions of young people have extensively been studied based on established categories of distinction, such as spatial mobility, social inequality, or educational aspirations. However, geographers have been less attentive to emotional or affective aspects accompanying transitional processes. However, research focusing on the nexus of emotions and transitions is able to show that emotions have powerful effects with respect to practices of categorizations and selections. For social scientists it is not only important to understand which effects emotions have on e.g. educational decisionmaking processes. Rather, they are eager to understand how emotions and "affects" (Pile, 2010; Thien, 2005) are being assembled and in which ways these affectual aspects relate to young people's geographies of education and aspiration (e.g. Brown, 2011; Christie, 2009; Pimlott-Wilson, 2016; Tse and Waters, 2013; Zembylas, 2012). As a consequence, emotional realms of transitions advance the discourse to a poststructural framing that acknowledges and analyses transitions also as ruptured, messy, affectual, and fluid.

In her article on emotional geographies in plural transitions of young people from disadvantaged socioeconomic backgrounds in Leipzig (Germany), Kathrin Hörschelmann demonstrates the benefit of this approach (see also Laketa and Suleymanova, 2017, in this special issue). Drawing on her participants' accounts of interpersonal conflicts and how these young people negotiate the resulting emotions in their diverse everyday experiences and institutional contexts, she shows that interpersonal conflicts evoke emotions well beyond the present moment and the local spatial context. To capture these interrelated movements, she argues, we have to focus on emotions not merely as bounded or as an embodied relation to place. Moreover, we may consider emotions "as an embodied medium through which time-spaces are brought into connection and boundaries are transgressed, maintained, and/or (re)produced" (Hörschelmann, 2018:31). Hörschelmann develops an approach of unbounded emotional geographies to examine how emotions also affect the education trajectories and future career options of her research participants. She suggests a way to do greater justice to the diverse and complex personal histories and subjectivities of young people. 


\subsection{Spaces and identities}

Subjects and subjectivity in particular involve endless points of reference, such as age, gender, sexuality, language, and place. These are constantly negotiated, differentiated, and set in relation to each other and are part of co-constructing fluid subjectivities of learning. Approaching subjects in learning and education from a post-structuralist perspective enables us to focus on fluidity, changeability, and the performance of identities in intersections with spaces of learning and education (e.g. Davis, 2006; Mulcahy, 2010; Thomas, 2005; Valentine, 2000; Mulcahy, 2017, in this special issue). From a relational perspective that conceptualizes spaces and places as "power-filled social relations" (Massey, 1994, 2005), spaces of learning can also be seen as ongoing processes constituted by temporary encounters between people and things. Such an approach helps to focus on questions that address power relations on various scales and in various encounters that produce spaces and identities of learning and education (e.g. Bauer, 2015; Kraftl, 2013; Landolt, 2013; Bitzi and Landolt, 2017, in this special issue; Laketa and Suleymanova, 2017, in this special issue). This approach puts places of learning in relation to other places of formal and informal learning and education (Leander et al., 2010; Valentine, 2000; Hörschelmann, 2018, in this special issue). It also brings the global, national, and local dimensions of the geographies of learning into a fruitful exchange (Hörschelmann and Schäfer, 2005, 2007; Jeffrey, 2010; Kölbel, 2015; Thieme, 2014). Finally, such an approach enables young people's geographies in learning and education to be examined as events emerging in interrelations in various and contradictory narratives, practices, policies, and educational discourses on interrelated scales (Bauer, 2016; Benwell, 2014; Müller, 2011).

In their paper, Suncana Laketa and Dilyara Suleymanova follow this line of thought and move the debate on to the role of education in nation-building processes and the formation of national identities. Their empirical work has been conducted in two quite different places. Both Tatarstan and Bosnia and Herzegovina are multi-ethnic and multi-religious societies confronted with politically divisive events. Laketa and Suleymanova ask an important question: "In what ways does a past that is muted within a school history curriculum continue to speak and structure the relationship of the school present?" (Laketa and Suleymanova, 2017:5, this special issue). They argue that pupils' subjectivities are produced in a negotiation of collective and official top-down educational discourses (represented through textbooks, for example) with the individual and resistant practices of teachers and pupils. In examining such negotiations, they elaborate the role of emotions in reproducing highly controversial pasts in the spaces of the school present. Their contribution highlights how educational spaces can turn into sites of learning where absent and/or muted pasts become alive and are linked to presences.
Barbara Bitzi and Sara Landolt's paper follows Mohammed, Reza, and Merhawit, three unaccompanied minor asylum seekers living in a collective centre for unaccompanied minor asylum seekers aged 12 years and older in Switzerland. These young people encounter several spaces of education, the internal school at the collective centre, public mainstream classes, and non-school spaces that are connected to school via social networks. Bitzi and Landolt thus examine how educational arrangements can produce feelings of belonging and non-belonging and highlight that these feelings are entangled with life experiences and the responsibilities of unaccompanied minor asylum seekers in their daily lives in Switzerland. Conceptually, they bring a relational thinking of spaces of education together with Judith Butler's work on subjection and unfold these in the context of refugee education.

\subsection{Education and assemblages}

Once young people in all their individuality and diversity enter formal education, they tend to become homogenized as a group or a class. The same process seems to apply to learning within education. Despite ongoing criticism, the imagination of the classroom as the location or the "black box" of formal learning tends to remain a principle that is hard to deviate from, both in educational research and in practice. Hence, we feel it is time to give more room to alternative imaginations and narrations. Scientists in educational research and geographies of education point out that post-structural concepts such as relational space and socio-material approaches to education enable us to understand classrooms and schools as networks, assemblages, and affective school datascapes (Fenwick and Edwards, 2010; Finn, 2016; Fox, 2009).

In her article, Dianne Mulcahy uses an assemblage approach to elaborate her concept of liminal spaces of learning, which assemble affects, bodies, and objects at a museum. Empirically, her argument is based on a 1-year video case study of 40 students' engagement with learning at three museum venues of Museums Victoria, an Australian organization. Interestingly, Dianne Mulcahy's explanation of liminal space knits together different threads of thought: Massey's "spatiality", which sees space as something that is permanently being made, and the Deleuzian metaphor of the rhizome, "characterized by openness, indeterminacy and movement" (Mulcahy, 2017, in this special issue). The rendering of the museum as a liminal space consequently invites a reimagined geography of learning and education.

A story that at this point may be further elaborated is the aspect of informal learning within formal education, because learning is like a free radical that may happen anywhere, anyhow, and with anything at any time and in line with, independent of, or even against someone's intentions (Bauer, 2016; Mulcahy, 2013). Such perspectives shed light on liminal or in-between spaces of learning, which have been studied in informal and outdoor settings, and the nexus of formal and 
informal learning during field trips (e.g. Daniels and Lorimer, 2012; Kraftl, 2013; Mills and Kraftl, 2014; Lorimer, 2003).

Dianne Mulcahy and Itta Bauer share an interest in actornetwork theory, science and technology studies, and assemblage theories. In their research projects, both authors translate these theoretical approaches into an engaged practice of research that critically examines educational structures as well as processes of learning.

The main argument in Itta Bauer's paper illuminates the widely neglected grey zones and the fuzzy logic at the heart of the selection machinery for higher education. The canton of Zurich is used in an empirical case study that examines the specific practices of educational selection at the threshold between primary and secondary education. Conceptually, the paper draws on Michel Callon's "framing and overflowing" (Callon, 1998) and Lotfi Zadeh's "fuzzy logic" (Zadeh, 2015) to examine the processes and consequences of the central entrance examination introduced to the cantonal school system in 2007. Whereas academic papers and educational reports focusing on the issue of educational structures and selection processes tend to concentrate on "hard" facts, big issues, and adult voices, Itta Bauer manages to write into her paper some hitherto unheard voices of young people experiencing educational selection in Zurich.

\section{Giving voice - outlook}

In this special issue, we aim to create a space that is open to the various and sometimes quite hybrid entangled forms of learning and education. These call for a more flexible understanding of the spatialities, rationalities and (im)materialities of learning in the broadest sense of the word.

Giving a voice to children and young people has always been a central aim within those studies of children and young people's geographies that have been grounded in radical, feminist, post-colonial, and assemblage thinking. We would like to join this private and political endeavour and explain our point of view.

It was our intention to collect papers that give voice to young people because by listening closely, we are able to learn a lot about their lives in times of economic austerity and insecurity (see Hörschelmann, 2018, in this special issue) in the global North. The voices of young people living in the global South are also represented in Bitzi and Landolt and Laketa and Suleymana's papers; not only have their minds, stories, and bodies travelled North, researchers have also encountered their voices, histories, and narrations on-site and made them visible in the papers.

However, despite our well-meaning intention to give voice to young people, researchers, material, and narrations from a variety of places and perspectives, we are well aware of the constraints on our endeavours.

This special issue on "Young People and New Geographies of Learning and Education" brings together several re- searchers that have insight into and contribute to the Germanand English-speaking debates. We are aware of the fact that this is only a limited perspective, because transgressing established power geometries and post-colonial boundaries in academia would demand the inclusion of research conducted and published in other languages, such as French, Spanish, Arabic, African, and Asian languages. A more inclusive and comprehensive collection of children and young people's geographies is assembled by Stuart Aitken and Tracey Skelton; this will draw a fuller picture of the research field and constitute a substantial reference work in 12 consecutively published issues (Skelton and Aitken, 2018).

As authors and theme issue coordinators, we hope that this special issue adds an exciting collection of papers with diverse geographical foci that address the various challenges to youths, young people's geographies, and geographies of education. We are also confident that our change in perspective on young people and learning can actually make a difference in understanding young people's lives and the practice and relevance of research.

Author contributions. Both authors prepared the manuscript together.

Competing interests. The authors declare that they have no conflict of interest.

Acknowledgements. We would like to thank Max Maisch and Ulrike Müller-Böker for their support not only in making the Workshop on "New Approaches to Children, Young People, and Education" at the University of Zurich (2014) possible but also facilitating our research on young people and education. We would also like to thank the anonymous reviewer for the constructive comments and the coordinating editor of this special issue, Myriam Houssay-Holzschuch, for her work and support along the way.

Edited by: Myriam Houssay-Holzschuch

Reviewed by: one anonymous referee

\section{References}

Aitken, S.: Geographies of Young People. The morally contested spaces of identity, Routledge, London and New York, 2001.

Ansell, N.: Sustainability: Life chances and education in Southern Africa, in: Sustainability: Life chances and livelihoods, edited by: Redclift, M., Routledge, London, 144-157, 1999.

Ansell N.: The discursive construction of childhood and youth in AIDS interventions in Lesotho's education sector: Beyond global-local dichotomies, Environ. Plan. D, 28, 791-810, 2010.

Bauer, I.: Approaching geographies of education differANTly, Child. Geogr., 13, 620-627, 2015. 
Bauer, I.: "Vital Assemblages" als Konzept einer sozio-materiellen Geographiedidaktik und Unterrichtspraxis, GW-Unterricht, 142/143, 62-70, 2016.

Bauer, I.: Framing, overflowing, and fuzzy logic in educational selection: Zurich as a case study, Geogr. Helv., 73, 19-30, https://doi.org/10.5194/gh-73-19-2018, 2018.

Benwell, M.: From the banal to the blatant: Expressions of nationalism in secondary schools in Argentina and the Falkland Islands, Geoforum, 52, 51-60, 2014.

Bitzi, B. and Landolt, S.: Unaccompanied minor asylum seekers processes of subject formation and feelings of belonging in the context of educational experiences in Switzerland, Geogr. Helv., 72, 217-226, https://doi.org/10.5194/gh-72-217-2017, 2017.

Brooks, R., Fuller, A., and Waters, J. (Eds.): Changing spaces of education: New perspectives on the nature of learning, Routledge, London and New York, 2012.

Brown, G.: Emotional geographies of young people's aspirations for adult life, Child. Geogr., 9, 7-22, 2011.

Brown, G., Kraftl, P., Pickerill, J., and Upton, C.: Holding the future together: Towards a theorisation of the spaces and times of transition, Environ. Plan. A, 44, 1607-1623, 2012.

Cahill, C.: Street literacy: urban teenagers' strategies for negotiating their neighbourhood, J. Youth Stud., 3, 251-277, 2000.

Callon, M.: An essay on framing and overflowing: Economic externalities revisited by sociology, Sociol Rev, Blackwell, Malden, 1998.

Christie, H.: Emotional journeys: Young people and transitions to university, Brit. J. Sociol. Educ., 30, 123-136, 2009.

Cuervo, H. and Wyn, J.: Reflections on the use of spatial and relational metaphors in youth studies, J. Youth Stud., 17, 901-915, 2014.

Daniels, S. and Lorimer, H.: Until the end of days: Narrating landscape and environment, Cult. Geogr., 19, 3-9, 2012.

Davis, B.: Subjectification: The relevance of Butler's analysis for education, Brit. J. Sociol. Educ., 27, 425-438, https://doi.org/10.1080/01425690600802907, 2006.

Evans, B.: Geographies of youth/young people, Geography Compass, 2, 1659-1680, 2008.

Fenwick, T.: Understanding transitions in professional practice and learning, Journal of Workplace Learning, 25, 352-367, 2013.

Fenwick, T. and Edwards, R.: Actor-Network Theory in education, Routledge, London and New York, 2010.

Finn, M.: Atmospheres of progress in a data-based school, Cult. Geogr., 23, 29-49, 2016.

Fox, S.: Contexts of teaching and learning: An actor-network view of the classroom, in: Rethinking Contexts for Learning and Teaching: Communities, activities and networks, edited by: Edwards, R., Biesta, G., and Thorpe, M., Routledge \& Francis, London and New York, 31-43, 2009.

Freytag, T. and Jahnke, H.: Perspektiven für eine konzeptionelle Orientierung der Bildungsgeographie, Geogr. Helv., 70, 75-88, https://doi.org/10.5194/gh-70-75-2015, 2015.

Gagen, E. A.: An example to us all: Child development and identity construction in early 20th-century playgrounds, Environ. Plan. A, 32, 599-616, 2000.

Holloway, S. L. and Jöns, H.: Geographies of education and learning, Trans. Inst. Br. Geogr., 37, 482-488, 2012.
Holloway, S. L. and Valentine, G. (Eds.): Child. Geogr.: Playing, living, learning. Critical Geographies, Routledge, London and New York, 2000.

Holloway, S. L., Hubbard, P., Jöns, H., and Pimlott-Wilson, H.: Geographies of education and the significance of children, youth and families, Prog. Hum. Geogr., 34, 583-600, 2010.

Hörschelmann, K.: Theorising life transitions: Geographical perspectives, Area, 42, 378-383, 2011.

Hörschelmann, K.: Unbound emotional geographies of youth transitions, Geogr. Helv., 73, 31-42, https://doi.org/10.5194/gh-7331-2018, 2018.

Hörschelmann, K. and Schäfer, N.: Performing the global through the local: Globalization and individualization in the spatial practices of young East Germans, Child. Geogr., 3, 219-242, 2005.

Hörschelmann, K. and Schäfer, N.: "Berlin is not a foreign country, stupid!": Growing up 'global' in Eastern Germany, Environ. Plan. A, 39, 1855-1872, 2007.

Jeffrey, C.: Geographies of children and youth I: Eroding maps of life, Prog. Hum. Geogr., 34, 496-505, 2010.

Johnston, R. J, Gregory, D., Pratt, G., and Watts, M. (Eds.): The Dictionary of Human Geography, Blackwell, Oxford, 2000.

Katz, C.: Growing up global: Economic restructuring and children's everyday lives, Minnesota University Press, Minneapolis, 2004.

Katz, C.: The angel of geography: Superman, Tiger Mother, and aspiration management, and the child as waste, Prog. Hum. Geogr., 1-17, https://doi.org/10.1177/0309132517708844, 2017.

Kölbel, A.: Youth, Aspiration, and Mobility: Young people debating their potential futures in Nepal, $\mathrm{PhD}$ thesis, University of Oxford, 2015.

Kraftl, P.: Geographies of Alternative Education. Diverse learning spaces for children and young people, Policy Press, Bristol, 2013.

Laketa, S. and Suleymanova, D.: Enacting the contested past: conflict narratives in educational spaces, Geogr. Helv., 72, 5-16, https://doi.org/10.5194/gh-72-5-2017, 2017.

Landolt, S.: Co-productions of neighbourhood and social identities by young men living in an urban area with delinquent youth cliques, J. Youth Stud., 16, 628-645, 2013.

Law, J.: After Method. Mess in social science research, Routledge, Oxon, 2004.

Leander, K. M., Phillips, N. C., and Haedrick Taylor, K.: The changing social spaces of learning: Mapping new mobilities, Rev. Res. Educ., 34, 329-394, 2010.

Lorimer, H.: The geographical field course as active archive, Cult. Geogr., 10, 278-308, 2003.

MacDonald, R., Shildrick, T., Webster, C., and Simpson, D.: Growing Up in Poor Neighbourhoods: The significance of class and place in the extended transitions of "socially excluded" young adults, Sociology, 39, 873-891, 2005.

Massey, D.: Space, Place and Gender, University of Minnesota Press, Minneapolis, 1994.

Massey, D.: For Space, Sage, London, 2005.

McDowell, L.: Transitions to Work: Masculine identities, youth inequality and labour market change, Gend. Place Cult., 9, 39-59, 2002.

Meusburger, P.: Bildungsgeographie. Wissen und Ausbildung in der räumlichen Dimension, Spektrum, Heidelberg, 1998.

Mills, S. and Kraftl, P.: Informal Education, Childhood and Youth, Geographies, Histories, Practices, Palgrave Macmillan, Basingstoke, 2014. 
Mulcahy, D.: Assembling the "accomplished" teacher: The performativity and politics of professional teaching standards, Educ. Philos. Theory, 43, 94-113, 2010.

Mulcahy, D.: Turning around the question of "transfer" in education: Tracing the sociomaterial, Educ. Philos. Theory, 45, 12761289, 2013.

Mulcahy, D.: The salience of liminal spaces of learning: assembling affects, bodies and objects at the museum, Geogr. Helv., 72, 109118, https://doi.org/10.5194/gh-72-109-2017, 2017.

Müller, M.: Education and the formation of geopolitical subjects, Int. Polit. Sociol., 5, 1-17, 2011.

Nayak, A.: Race, Place and Globalization: Youth Cultures in a Changing World, Berg, Oxford and New York, 2003.

Pimlott-Wilson, H.: Individualising the future: The emotional geographies of neoliberal governance in young people's aspirations, Area, 49, 288-295, 2016.

Pile, S.: Emotions and affect in recent human geography, Trans. Inst. Br. Geogr., 35, 5-20, 2010.

Rérat, P.: Migration and post-university transition. Why do university graduates not return to their rural home region?, Geogr. Helv., 71, 271-282, https://doi.org/10.5194/gh-71-2712016, 2016.

Robertson, S., Harris, A., and Baldassar, L.: Mobile transitions: A conceptual framework for researching a generation on the move, J. Youth Stud., 21, 203-217, 2018.

Robinson, P. A.: Learning spaces in the countryside: University students and the Harper assemblage, Area, 38, https://doi.org/10.1111/area.12379, 2017.

Skelton, T.: Research on youth transitions: Some critical interventions, in: Young People in Risk Society: The Restructuring of Youth Identities and Transitions in Late Modernity, edited by: Cieslik, M. and Pollock, G., Aldershot, Ashgate, 100-116, 2002.
Skelton, T. and Aitken, S. (Eds.): Establishing Geographies of Children and Young People, Springer, Singapur, 2018.

Skelton, T. and Valentine, G. (Eds.): Cool Places: Geographies of Youth Cultures, Routledge, London and New York, 1998.

Smith, D. P., Rérat, P., and Sage, J.: Youth migration and spaces of education, Child. Geogr., 12, 1-8, 2014.

Thieme, S.: An international degree, social ties and return: When international graduates make a career back home in Kyrgyzstan, Int. Asianforum, 45, 113-128, 2014.

Thien, D.: After or beyond feeling? A consideration of affect and emotion in geography, Area, 37, 450-454, 2005.

Thomas, M. E.: "I think it's just natural": The spatiality of racial segregation at a US high school, Environ. Plan. A, 37, 12331248, 2005.

Tse, J. K. H and Waters, J. L.: Transnational youth transitions: Becoming adults between Vancouver and Hong Kong, Glob Netw, 13, 535-550, 2013.

Valentine, G.: Exploring children and young people's narratives of identity, Geoforum, 31, 257-267, 2000.

Valentine, G.: Boundary crossings: Transitions from childhood to adulthood, Child. Geogr., 1, 37-52, 2003.

Zadeh, L. A.: Fuzzy logic: A personal perspective, Fuzzy Set. Syst., 281, 4-20, 2015.

Zembylas, M.: Transnationalism, migration and emotions: Implications for education, Globalisation, Societies and Education, 10, 163-179, 2012. 